\title{
A Study on the Democratic Style of Leadership
}

\author{
Dr. L. Jibon Kumar Sharma ${ }^{1}$ Dr. S. Keshorjit Singh ${ }^{2}$ \\ ${ }^{1}$ Director, ${ }^{2}$ Faculty member \\ Manipur Institute of Management Studies, \\ Manipur University (A Central University) Imaphal, Manipur, India
}

\begin{abstract}
The paper studies democratic style of leadership and how the style influences the practices of leadership. Leadership can be categorized based on the level of involving team members and participating in the decision making process. The study is exploratory in nature and attempts to explore and analyze the democratic aspects of leadership style and its influence in the practices of leadership. The study adopts survey and interview techniques and 25 leaders of the state Manipur, India are considered as sample. The primary data are collected using interview cum questionnaire method from the top executives of the selected 25 organizations and also from two immediate subordinates of the sampled executives of the selected organizations and from two immediate subordinates of the sampled executives. The responses of the followers become essential to crosscheck the practices of the leaders. The study highlights how the democratic style influences the practice of leadership.
\end{abstract}

\section{General Terms}

Leadership, Democratic style, Decision making, Involvement, Participation

\section{Indexing Terms}

Decision making, Involvement of subordinates, Ideas and inputs, Mediation, Skill sharing, and Motivating factor,

\section{Academic Discipline And Sub-Disciplines}

Social Science

\section{Subject Classification}

Management

\section{Coverage}

Democratic Style of Leadership in Leadership Study

\section{Type (Method/Approach)}

Exploratory Research Approach

\section{INTRODUCTION}

Leadership is a universal phenomenon and as old as history of human (Bass, 1990). Democratic leadership plays key role in democratic movements (Adorno, 1965; Gastil, 1994; Kunter, 1965). According to Anderson (1959) democratic leader is one who encourages participation in decision making and democratic leadership relates with higher morale in most leadership situations. Democratic leaders offer guidance to group members, participate in the group and allow input from subordinates. Democratic leadership is termed as the most effective leadership style (Lewin and White, 1939). Democratic leadership relates with increased follower productivity, satisfaction, involvement, and commitment (Hackman \& Johnson, 1996). They delegate authority to followers and also give ongoing support and focus for the challenging works. Often this style of leader has the vision to realize what people need and ensure that they get it. In the process they generate successful and sustainable organizations. Member satisfaction are greater under democratic leadership (Bass, 1990; Stogdill, 1974). They have confidence and trust in their people. When issues arise and decisions must be made, relevant and varied participants are involved to discuss the situation and a majority view is taken as the final decision. However the impediments to democratic leadership are time consuming process in taking decision though the participation in the process enhances the productivity (Denhardt \& Denhardt, 2003; Hackman \& Johnson, 1996).

The study is exploratory in nature and attempts to explore and analyze the democratic styles of leadership and for the purpose 25 leaders of the state Manipur, India are considered. The sample comprises of both the private and government sector. In the government sector eighteen departmental heads including six deputy commissioners of six different districts of the state are chosen and in the private sector seven private organizations are chosen based on the number of employees and profitability of the organizations. Primary data are collected using interview cum questionnaire method from the top executives of the selected organizations and from two immediate subordinates of the sampled executives. The responses of the followers become essential component to crosscheck the practices of the leaders. The required data for the present study is mainly based on the primary sources supplemented by secondary. The paper assesses style of the sampled leaders with reference to democratic style of leadership. For the purpose, eight statements relating to leadership behaviors and actions have been used. The statements were related with the following parameters:

(i) Decision making

(ii) Involvement of subordinates

(iii) Ideas and inputs

(iv) Employees' participation

(v) Motivating factor

(vi) Participation and skill sharing

(vii) Work with employees

(viii) Mediation

The sampled leaders were called upon to indicate the degree to which they stand on a five point rating scale for every statement:

Almost Always True (5)

Frequently True (4)

Occasionally True (3) 
Seldom True (2)

Almost Never True (1)

Two immediate subordinates for each sampled leader were also cross-examined. The score on the leader's table provide information about how the leaders see themselves and the score of the followers highlight their perception of the same leader. A brief detail for each parameter and analysis thereof are shown in Table (1).

\section{DECISION MAKING}

Decision making is one of the most important functions of leadership. It is true that every leader takes decisions but the ways of making decisions vary from one leader to another. The variation makes a difference in style of leadership. Their way of decision making is an important input for identifying the leadership style.

An attempt has been made to determine the style of the sampled leaders by putting a statement regarding involvement of people in making decision making process. The median scores for the sampled leaders correspond to the highest scale of response category - 'Almost Always True' with a score of 5 in the five point scale (Table (1)). The result shows that the sampled leaders involve people in taking decision. The median score of the follower is 'Frequently True' (4). According to the rating of the followers, the sampled leaders have slightly overrated however they agree that the sample leader involve people.

\section{INVOLVEMENT SUBORDINATES}

Leaders need ideas and inputs from the subordinates. Democratic leaders act like a coach who have the final say but gather information and take inputs from staff members for future developments in the best interest of the employees and stake holders.

It has been observed from the table that the median scores for both the sampled leaders and followers correspond to the second highest rating of response category -- Frequently True (4) (Table (1)).. So the sampled leaders feel that they need the ideas and input from subordinate for upcoming plans and ventures. The sampled followers also agree.

\section{IDEAS AND INPUTS}

The changes taking place in technology, demographics, markets, consumers and their preferences in economies have significant impacts on organizations. The leader examine how to response to these environmental changes and what strategies to adopt. Clearly this exercise is not self-contained, rather people involvement, contribution and conceptualizing new ideas are required and different possible inputs are taken from the employees.

The median scores for the sampled leaders is -- Almost Always True (5) (Table (1)). They discuss with their employees to get their input and advice for developing strategy and conceptualizing new ideas. The median score for the followers' on this category falls at the third highest rating of response category -- Occasionally true (3). According to the rating of the followers, the sampled leaders have overrated their responses on the discussed issue. They occasionally discuss with their employees.

\section{EMPLOYEES PARTICIPATION}

The fourth statement is regarding encouragement of employees to participate in the decision making process. A good democratic leader develops moral and esprit de corps for his employees. Democratic leader has confidence and trust in their employees and encourage them to participate in the decision making process.

The responses of the sampled leaders and their followers regarding employee's participation in decision making process are shown in Table (1). The median score for the sampled leaders is at the highest scale - 'Almost Always True' (5). This result infers that the sampled leaders encourage their employees to participate in the decision making process. The followers have rated the sample leaders in this category. The median score for the sampled followers corresponds to third scale of response category 'Occasionally True' (3). There is a gap between the two median scores. According to the sampled followers their leaders have overrated on this parameter-employees' participation. The sample leaders occasionally encourage their employees to participate in the decision making process.

\section{MOTIVATING FACTOR}

A democratic leader influences employees' motivation through participation and empowerment. He or she motivates his or her team by empowering them to direct themselves, and guide them with a loose reign.

In the light of the above discussion attempt has been made to study the motivating factor the sampled leaders to their employees. The median scores for the sampled leaders is 'Almost Always True' (5) (Table (1)). The sampled leaders felt that motivating their employees is participating in the development of processes. According to the sample follower the statement is frequently true (Table (1)). Both the leader and follower agree that participation is encouraged.

\section{PARTICIPATION AND SKILL SHARING}

A democratic leader believes in the capabilities and skill of his or her employees. He or she involves his or her employees widely in many organizational activities. He or she thinks that the main motivating factor for the employee is participation and skill sharing. The responses of the sampled leaders and their followers regarding employee's participation and skill sharing are shown in Table (1). The sample leader almost always involves their employees widely in many organizational activities.

The result highlights that the sampled leaders have thought that the main motivating factor for their employees is participation and skill sharing - median score is 'Almost Always True' (5). Followers have highlighted this aspect as 'Frequently True' (4). Hence, there is no disagreement regarding this aspect. However, according to the response of the followers the leaders have rated themselves slightly more in this aspect.

\section{WORK WITH EMPLOYEES}


The democratic leadership style is also called the participative style as it encourages employees to be a part of the decision making. Democratic leaders try to understand problems of their employees and work with them to identify the problem and bring solutions. According to the sample leaders they have worked with their employees whenever they faced problem and brought a solution. For them it is almost always true (Table (1)). It is frequently true for the sample followers. Both leader and follower agree that the leader worked with their employees whenever they faced problem and brought a solution.

\section{MEDIATION}

A democratic leader is a coach. He or she develops team spirit and high moral among the employees. A leader of this style mediates for others and provides clear feedbacks. Both the leader and follower agree that the sample leader frequently mediates and give clear feedbacks (Table (1)). The responses of the leader and their subordinates tally which is 'Frequently True'. So the leaders encourages team sprit and high morale among the employees.

\section{OVER-VIEW}

The median score for the sampled leaders falls at the highest rating scale - 'Almost Always True' (Table (2)). This result indicates that the sampled top executives of organizations in Manipur are highly democratic in their leadership practices. In other words, they delegate authority to followers in making decisions. They took the ideas and inputs from the followers for upcoming plans and strategies. They motivated the followers through participation in organizational activities. They also worked with the followers and mediated for them. The followers supported their leaders' democratic practices. This is evident from the median score - 'Frequent True' (Table (2)).

An important factor making democratic style significant is because majority of the sampled leaders are from government and public sectors organizations. There are few private sector organizations in Manipur. The bureaucratic officers who are considered as sampled leaders in the study felt that the final decision makers were not them but higher authorities. For example the Deputy Commissioners highlighted that they only give suggestions for making decisions but the final decision are made at cabinet levels. The sampled leaders recognized that people are less competitive and more collaborative when they are working on joint goals. They also agree that collective decision is better than individual decision which can be achieved only when leaders are democratic in their styles. The sampled leaders from the government and public sectors felt that they involve their subordinates in the decision making process. These sampled leaders were of the opinion that they are public servants and work for the upliftment of the state and for the society at large.

Table (1): Democratic Leadership Style

\begin{tabular}{|l|l|l|l|}
\hline \multirow{2}{*}{$\begin{array}{c}\text { SI. } \\
\text { No }\end{array}$} & \multirow{2}{*}{ Parameters } & \multicolumn{2}{c|}{ Median score } \\
\cline { 3 - 4 } & & \multicolumn{1}{|c|}{$\begin{array}{c}\text { Leaders } \\
\text { (Scale) }\end{array}$} & $\begin{array}{c}\text { Followers } \\
\text { (Scale) }\end{array}$ \\
\hline 1. & Decision making & Almost Always True (5) & Frequently True (4) \\
\hline 2. & Involvement of subordinates & Frequently True (4) & Frequently True (4) \\
\hline 3. & Ideas and inputs & Almost Always True(5) & Occasionally True(3) \\
\hline 4. & Employees' participation & Almost Always True(5) & Occasionally True(3) \\
\hline 5. & Motivating factor & Almost Always True(5) & Frequently True (4) \\
\hline 6. & Participation and skill sharing & Almost Always True(5) & Frequently True (4) \\
\hline 7. & Work with employees & Almost Always True(5) & Frequently True (4) \\
\hline 8. & Mediation & Frequently True (4) & Frequently True (4) \\
\hline
\end{tabular}

Table (2): Democratic Leadership Style

\begin{tabular}{|c|c|c|c|c|c|c|c|}
\hline \multicolumn{4}{|c|}{ Leader } & \multicolumn{4}{|c|}{ Follower } \\
\hline $\begin{array}{l}\text { Response } \\
\text { category }\end{array}$ & $\begin{array}{l}\text { No. of } \\
\text { respondents }\end{array}$ & $\begin{array}{l}\text { Cumulative } \\
\text { frequency }\end{array}$ & $\begin{array}{l}\text { Median } \\
\text { score }\end{array}$ & $\begin{array}{l}\text { Response } \\
\text { category }\end{array}$ & $\begin{array}{l}\text { No. of } \\
\text { respondents }\end{array}$ & $\begin{array}{l}\text { Cumulative } \\
\text { frequency }\end{array}$ & $\begin{array}{l}\text { Median } \\
\text { score }\end{array}$ \\
\hline $\begin{array}{l}\text { Almost } \\
\text { always true }\end{array}$ & 112 & 112 & $\begin{array}{c}\text { Almost } \\
\text { always true }\end{array}$ & $\begin{array}{l}\text { Almost } \\
\text { always true }\end{array}$ & 75 & 75 & \\
\hline $\begin{array}{l}\text { Frequently } \\
\text { true }\end{array}$ & 53 & 165 & & $\begin{array}{l}\text { Frequently } \\
\text { true }\end{array}$ & 101 & 176 & $\begin{array}{c}\text { Frequently } \\
\text { True }\end{array}$ \\
\hline $\begin{array}{l}\text { Occasionally } \\
\text { true }\end{array}$ & 23 & 188 & & $\begin{array}{l}\text { Occasionally } \\
\text { true }\end{array}$ & 66 & 242 & \\
\hline Seldom true & 12 & 200 & & Seldom true & 36 & 278 & \\
\hline $\begin{array}{l}\text { Almost never } \\
\text { true }\end{array}$ & 0 & 200 & & $\begin{array}{l}\text { Almost never } \\
\text { true }\end{array}$ & 2 & 280 & \\
\hline Total & & 200 & & Total & 280 & 281 & \\
\hline
\end{tabular}

\section{REFERENCES}

[1] Bass, B. M. (1990). Bass \& Stogdill's handbook of leadership: Theory, research \& managerial applications (3rded.). New York: Free Press.
[2] Adorno, T. W. (1965). Democratic leadership and mass manipulation. In A. W. Gouldner, Studies in leadership: Leadership and democratic action (pp. 417-421). New York: Russell \& Russell. 
[3] Gastil, J. (1994). A definition and illustration of democratic leadership. Human Relations, 47, 954971.

[4] Kunter, B. (1965). Elements and problems of democratic leadership. In A. W. Gouldner, Studies in leadership: Leadership and democratic action (pp. 459- 467). New York: Russell \& Russell.

[5] Anderson, R. C. (1959). Learning in discussions: A resume of the authoritarian-democratic studies. Harvard Educational Review, 29, 201-212.

[6] Lewin and White (1939). "Leadership Practice in Relation to Productivity and Moral," Group Dynamics Research and Theory, $2^{\text {nd }}$ Ed, New York, Row Peterson

[7] Hackman, M. Z., \& Johnson, C. E. (1996). Leadership: A communication perspective (2nd ed.). Prospect Heights, IL: Waveland Press.

[8] Stogdill, R. M. (1974). Handbook of leadership: A survey of theory and research. New York: Free Press.

[9] Denhardt, J. V., \& Denhardt, R. B. (2003). The new public service: Serving, not steering. Armonk, NY: M. E. Sharpe.

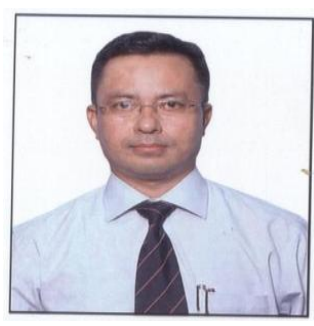

Ist Author's Biography: Dr. L. Jibon Kumar Sharma has around eighteen years of experience in teaching MBA students at Manipur Institute of Management Studies, Manipur University, Imphal, India.

Before pursuing his career in teaching he worked in the industry. He has published in national and international journals of repute. His area of interest is in the area of integration of social entrepreneurship and strategic management perspective, leadership and sustainable development.

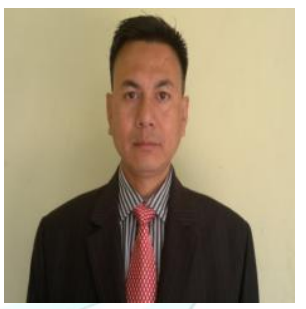

2nd

Author's

Biography: Dr.

S.Keshorjit Singh has more than a decade of experience in teaching MBA students at Manipur Institute of Management Studies, Manipur University, India.

He has published in journals of repute. Before joining the Institute he worked at $P \& G$ India for three years. His area of interest is leadership and strategic management. He has more than nine years of experience in research in the field of leadership 